\title{
Acid attacks: Issues and Challenges
}

\author{
Mr. Kiran Ranganath Kale \\ Assistant Professor, Sarsenapati Hambirrao Mohite Law College, Rajgurunagar, Pune, \\ Maharashtra, India \\ E-mail:kirankale2010@rediffmail.com
}

\begin{abstract}
Acid attack is against the indivual but consequences are universal; hence I think it is one kind of deep rooted social evil. As a learner of law we all are well aware that crime is against world at large or against the society. Now this acid attacks demeans the society and humanity. It reflects crony of human beings which is always hidden and not apparent. Over the years the gravity of this heinous crime has centralized Research scholars, thinkers' Social activist, Legislatures, law students' judges as well to make out way to curb this paranoia. In A.K. Gopalan's case Justice Patanjali shashtri said that "man is rational beings desires to do many things but in civil society his desires will have to be controlled with the exercise of sillier desires of other indivual." And not pouring acid on him or her. Because the main reasons behind commission of this brutal act are unwarranted desires like rejection of love marriages not love but proposal of marriages, refusal of dowry, rejection of sexual demands, property dispute, family conflict, disputes of live-in relationships though desires of human beings cannot be legislated but behavior can be controlled by penalizing it. The acid attack is unpredicted and permeated violence against beauty and body of the person; this is the only attack which can be done against inherent things of the body rather than bodily harm to the person. Those beautiful things of the victims can be targeted which are impossible to digest to the acid throwers. Acid attack is not only crime but also brutal violence that shows the gravity of the act of the thrower. This leads several long term consequences like blindness, disfigurations of the face and body, having negative felling to live along with society. Hence this evil must be eradicated before it grows in civil society
\end{abstract}

Keywords: Acid attacks, Human Rights, Punishment. 


\section{Introduction:}

In these days, crimes involve certain factors like the revenge, brutality, corny conduct and paronia $^{1}$. Acid attack is one of those it is reaction rather that action of human beings towards the act certain person which shows brutality of human mind against specific thing. This acid attack violets fundamental rights, human rights and the Universal Declarations of human rights "No person shall be deprived life and liberty except according to procedure established by law" " because everyone has the right to life, liberty and security of person ${ }^{3}$. which cannot be diluted on the ground of race sex caste, butey and identity of person. You may love or hate someone's but you can't destroy his or her butey and happiness which is inherent. Law of the land of this country allows people to live people can live withought fear. Then why the women and beautiful girls should be living in fear every day. It is true that Acid attacks can understand nature and consequences of their conduct; have intentionally using this harmful liquid against their ill-will ${ }^{4}$. They are always male members. And they are always under impression that women need to be controlled by any lawful or unlawful means, and they do it by using force, coercion, fraud and undue influence "to put women in their place". Some of them are attacked because of their beauty; even they did not know that why and when attack will occur ${ }^{5}$. Children are too second hand victims to attacks on their mothers that mean this endless cycle of victims; if a mother having kid is being attacked then both mother and her kid will suffer; hence I think law should be made not only for existence but also for goverence. Because most of the cases that intention of the attackers does not murder or end if life of the victim, but to give pain and to disfigure his or her face, body and mind. This act of the attacker will be resulted in permanent blindness, permanent dislocation of bones ${ }^{6}$ .dissolution ear and nose .social stigma is permanently attached to those victims which would become identity of them. Though acid attack does not come under the preview of deadly weapon but it is known to be very potent weapon of offence and assault ${ }^{7}$. Those are the victims they need to live with this stigma and pain. They face social, mental. Physical and emotional torture. They lost everything it would be difficult to family members to behave with her normally even though they are trying to live. There is no possibility to getting married and if they are already married they might be left alone by their spouse even children of the woman fear the ugly face of their mother; untimely victims are not only those on whom acid has been thrown but also those who are the closely and very relative to her. Hence this acid attack needs to tackle with special legislation. On the other hand culprits would be free on bail or got punishments which are very less.

\footnotetext{
${ }^{1}$ Pune mirror on feb,2021

${ }^{2}$ Art21 of the Indian Constitution

3 Art 3 of the Universal Declarations Of Human Rights

4 The times of India march21,2018

5 The wire Augest06,2016

${ }^{6}$ News Click Jan01.2020

7 Times now news.com Nov25,2020
} 


\section{Issues and challenges:}

In acid attacks, the intensity of burning can be calculated but harm and pain caused to the victim and her or his family members cannot be measured. In acid attacks criminal uses nitric acid, sulphuric acid or hydrochloric acid which can burn skin easily and bones get melted. After the incidents sometimes victim needs plastic surgery which is very costly and not possible to afford general people. Hence acid attacks are not just violation of natural rights, human rights or fundamental rights of the victims but it is big challenge to medical fraternity to serve and restore position of the victim of the $\operatorname{attack}^{8}$.

\section{- Medical treatment issues:}

Acid attacks are grave injuries and preplanned brutal acts hence its gravity can reach to the body and mind of the victims which would become challenge to medical practioners as well. When any patient rather that victim brings to the hospital for his her treatment then it is big challenge to medical partner to rinse the affected area using as much as clean water and medical substance without causing damage to the original part of the body ${ }^{9}$. By carefully removing the chemical and any contained clothing. Acid attack victims are facing physical as well as psychological consequences of such attack.

\section{- First aid treatment to the victims:}

It should be fundamental right of every victim of acid attach to get first aid treatment as soon they met with an incident. It comes under impression that "No person shall be deprived his life and liberty except produce established by law ${ }^{10 "}$ In spite of all legal formalities victim should get treatment from both private or government hospital. It leads to dramatic difference to the amount of pain, fear and mental shock. With respect to get first medical aid to the acid attack victims it is expected that some of the important aspects like role of legislation, judiciary and hospitals should explain the mandatory free first medical aid to the acid attack victims. Sometimes victims might be unable to explain his or her side hence it is very necessary to follow medical ethics rather than those legal formalities but on the other side there must be expression provisions to exclusion or need to suspend of these legal formalities at the first step of treatment of acid attack victim so that medical practioners can perform very well.

\section{- Legal formalities and Right to life of the Victim:}

Right to live with dignity cannot be curtailed by these attacks; if the state is custodian and guardian of its subject ${ }^{11}$.acid attacks are increasing day by day. The culprits or attackers are followings by new ways of committing crime, which is always big concern not only to the

\footnotetext{
${ }^{8}$ Rabidrnath Karmarker Forensic Medicine and Toxicology: theory oral and practice (2006)

${ }^{9}$ Instructions given by helpline number 999

10 Art.21 of the Indian Constitution

11 Principles of political science Dr. A.Kapoor, Kindle edition
} 
victims but also to the survivors ${ }^{12}$; it is one kind hush-hush act of person who is going to pour acid hence there is no possibility of use of right of self defence ${ }^{13}$ from victims end. It is clear that without having express provision and penal laws it is impossible to control completely this ongoing violence. It is starting from stocking to sales and use of acids, the investigations, prosecutions and convictions must be taken to a different level of excellence and must happen seamlessly to ensure that the harshest and the most severe punishment is given to these violent deviants who use acids ${ }^{14}$. Just as surely and swiftly as sulphuric acid takes merely 30 seconds to permanently maim or kill an unsuspecting victim. On the other side though defence of acid attack would be in defaceable because of its so sudden nature of occurrence but it gives right to the victim those around the victim to use proportionate force to defend, disarm and apprehend the assailant. Primarily due to ignorance and fear, this provision has hardly ever been used. The law does not expect the onlookers to be passive spectators and the vulnerable should know the rights and duties conferred on all. Unfortunately, seldom have people taken advantage of this provision and apprehended or even accosted the attackers. Such incidents are bound to shock and numb the victims and those who are in close proximity -- it would be a major deterrent if there is a befitting response but the suddenness of the attack and the stealth make it extremely difficult if not impossible to show appropriate resistance ${ }^{15}$.

\section{Compensation to the victims:}

This is the crime in which victims could be those who are around him or her at the time of acid attack. Compensation should go to not only victims, and survivors but also those who are there, if they were affected due to the acid attack. There is no specific legislation in this regard which deal with these problems. Compensation in the monetary form is necessary to recover the victim from injury but criminal should get lesson over his act. Here he is using another illegal means sometimes compensation in the monetary form would be adequate relief.

\section{Criminal injuries compensation board}

Once upon a time there was specific law in India to deal with the cases of acid attack. Law provides voluntarily causing grievous hurt by dangerous weapons or means ${ }^{16}$ was not so effective in dealing but it is not included in acid attack. In India law on acid attack nither explain the scope of gravity of the neither offence nor gives adequate relief in the form of compensation. The compensation is an important part of this crime but there is no separate board of compensation for help of victims of the acid attack. Now the compensation payable

\footnotetext{
$12226^{\text {th }}$ Report of Law commission of India

13 Sec 96 to 106 of Indian Penal code, 1860

14 Vikram Singh Ex-DGP on Times news.com on Nov2020

15 Sec 100(vii) of the Indian Penal Code, 1860

16 sec 326 Bare Act, of Indian Penal code ,1860
} 
by the state government under section 357A shall be in addition to the payment of fine to the victim under section $326 \mathrm{~A}$ of the Indian penal code ${ }^{17}$.so I think compensation to the victims should be decided by the compensation board. The criminal injuries compensation board is one of the remedial bodies and can provide assistance to the victims and saviors of the victim.

\section{Present legal position of acid attack in India:}

Today, we don't have any specific legislation in Indian though this crime in increasing day by day. Legislation should be clear on who suffers physical and mental injury, surviving spouse or child of a homicide victim, a person who was dependent on the victim, who was around the victim at the time of attack, if he gets injured as a result of a crime and heinous act of the criminal. after the recommendation of Justice verma committee that All hospitals, public or private, whether run by the Central Government, the State Government, local bodies or any other person, shall immediately, provide the first-aid or medical treatment, free of cost, to the victims of any offence covered under section 326A, 376, 376A, 376B, 376C, 376D or section $376 \mathrm{E}$ of the Indian Penal Code, and shall immediately inform the police of such incident ${ }^{18}$. sec $326 \mathrm{~A}^{19}$ says that Whoever causes permanent or partial damage or deformity to, or bums or maims or disfigures or disables, any part or parts of the body of a person or causes grievous hurt by throwing acid on or by administering acid to that person, or by using any other means with the intention of causing or with the knowledge that he is likely to cause such injury or hurt, shall be punished with imprisonment of either description for a term which shall not be less than ten years but which may extend to imprisonment for life, and with fine. Judiciary is taking certain steps when a man was thrown acid on his estranged wife because she refused to cohabit with him. The wife suffered permanent disfigurement and loss of one eye. The accused was convicted under Section 307 and was imprisoned for 7 years ${ }^{20}$. It is one of the most famous cases involving acid attack. The accused threw acid on a girl, Hasina, for refusing his job offer. This deeply scarred her physical appearance changed the colour and appearance of her face and left her blind. The accused was convicted under Section 307 of IPC and sentenced to imprisonment for life. Compensation of Rs. 2, 00,000/in addition to the Trial Court fine of Rs 3,00,000 was to be paid by the accused to Hasina's parents $^{21}$.

\footnotetext{
${ }^{17} 226^{\text {th }}$ report of law commission of India

${ }^{18} \mathrm{Sec} 357$ of the Indian Penal Code

19 Indian penal code 1860

${ }^{20}$ Devanand V State 1987 (1) crimes314

${ }^{21}$ State of Karnataka by Jalahalli Police Station vs. Jospeh Rodrigues Decided on 22/8/2006
} 


\section{Conclusion:}

In Acid attack cases there should be speedy trial and investigation must be completed within specific days. If he fails to submit it within specific day then report of each day should be brought on record and action should be taken against him. And case can be disposed as per the evidence as early as possible. The punishment needs to more stringent so that no one can think like that. The reasons for this attack are refusal of marriage proposal; refuse to live-inrelationship, one side love, hence. The nongovernmental organizations can play important role in voice of acid attack victims. In case of acid attack victim punishments to the criminal is not whole aim but also rehabilitation and resettlement of the victim is also paramount target. Hence it is necessary to provide medical help from both hospital and government to the victim as soon as possible and the police should properly investigate the case; they should get special training, legislation or judiciary can fix certain rules and guidelines in this regard. There should be complete ban on sale of acid, because it is not commodity which needs to keep in open market. There are unreported cases of acid attacks where victims die especially in rural areas. Hence Acid should not easily available in the market because this thing which criminal can make it at his home. Acid attack has very long effect on the life of the victim who is facing torture, pain and damage day to day life so these things should stop before humanity dies. 